\title{
Exploring ESL Teacher Beliefs and Classroom Practices of CLT: A Case Study
}

\section{Mohammad Mosiur Rahman}

Graduate Research Student, School of Languages, Literacies and Translation, Universiti Sains Malaysia, Penang, Malaysia, mosiurbhai@gmail.com

Manjet Kaur Mehar Singh

$\mathrm{PhD}$, Senior Lecturer, School of Languages, Literacies and Translation, Universiti Sains Malaysia, Penang, Malaysia,manjeet@usm.my

\section{Ambigapathy Pandian}

Prof., Faculty of Language Studies and Communication Studies, Universiti Malaysia Sarawak, Kuching, Malaysia.pambigapathy@unimas.my

This paper presents a case study that investigated and compared the stated beliefs and observed classroom practices relating to Communicative Language Teaching (CLT) of two ESL teachers. The findings of the study revealed that both the teachers hold similar complex beliefs that mostly contradict the philosophy of CLT. The practices were not in line with their stated belief or CLT principles either. The findings also indicate that teachers indeed possess a set of complex beliefs that are not always realized in their classroom practices for a variety of potential reasons: some of these might be directly related to the context of teaching. Additionally, this study found that by articulating and reflecting on his beliefs, the teacher became more aware of the meaning and impact of these beliefs on his classroom practices. Some implications of future studies have also discussed.

Keywords: teacher beliefs, ESL teachers, teacher reflection, communicative language teaching, error correction

\section{INTRODUCTION}

The need to communicate effectively in the modern world is indisputable and in this context the demand of learning English as the international language among the nonnative speakers of English is growing daily (Richards, 2006). In relation to the growing interest of achieving communicative competence, Communicative Language Teaching (CLT) was developed as a response to previous structure-based approaches. CLT is not a recent innovation in language teaching, in fact, it can trace its root to the early 1960s

Citation: Rahman, M. M., Singh, M. K. M., \& Pandian, A. (2018). Exploring ESL Teacher beliefs and Classroom Practices of CLT: A Case Study. International Journal of Instruction, 11(1), 295-310. https://doi.org/10.12973/iji.2018.11121a 
(Richard \& Rodgers, 2001). Contrary to traditional structure based approaches to language teaching, CLT emphasises the development of communicative competence of learners. This involves knowledge of a language that facilitates a speaker to use the language or linguistic system efficiently and appropriately for meaningful communication in a speech community (Richard \& Rodgers, 2001). Arguably though, according to Larsen-Freeman and Anderson (2011), Communicative Language Teaching (CLT) is the most effective method or approach of teaching language to develop learners' communicative ability. It is also the most popular method in the context of teaching English as a second language (ESL) and English as a foreign language (EFL).

In the past 20 years, CLT has been incorporated in the English language curriculum in most areas of Asia and Africa (Orafi \& Borg, 2009) where English is being used as a second or foreign language. Several studies of CLT-based English Language Curriculum innovation indicate there is a mismatch between policy makers and ground reality in the implementation of CLT. According to Nunan (2003), CLT is not compatible with the Asian context, and thus, the CLT based curriculum has failed to spread in most of the countries. CLT research indicates that the implementation of CLT largely depends on teachers' beliefs about CLT and that belief influences their instructional practices (Feryok, 2008). In Malaysia, Pandian (2002) reported that despite the introduction of CLT into the classroom, teachers went back to the old practiced methods of teaching and facing weak innovation. In Japan, according to Hampshire and Burns (2015), it is impossible to bring a CLT led curriculum into Japanese classrooms. Similarly, in Taiwan, Chang and Goswami (2011) pointed out that teachers' existing beliefs impact the English classrooms and inhibits CLT in Taiwanese schools. In Bangladesh, teachers' long practiced language teaching method still can be traced in their practice, which is not allowing CLT take place in the classroom (Kirkwood, 2013).

According to second language education studies, teachers hold a complex set of beliefs regarding pedagogical practices. For example, teachers' instructional decisions have been found to be shaped by teacher beliefs (Borg, 2003; Phipps and Borg, 2009). Richards (1996) pointed out that teachers' beliefs reflect individual philosophies of teaching. However, most commonly, teachers' beliefs are referred to as what teachers know, believe, and think (Borg, 2003), and teachers do have their own existing beliefs as well as beliefs among themselves and compete with each other. However, despite having many different and competing beliefs, the relationship between their beliefs and their classroom practices is definite (Andrews, 2003). Contrary to this, many researchers found a negative relation between teachers' belief and practice. Even though teachers believe something, in the reality he or she cannot necessarily act upon those beliefs given contextual hindrances found in classrooms, schools and communities (Borg, 2003). Similarly, Ellis (2004) stated, not all teachers state their belief accurately in relation with their classroom and there can be a probable mismatch between their belief and behaviour or practice in the classroom.

Given these considerations, the aim of the present study is to explore the relationship between teachers' beliefs and classroom practice of the principles of CLT in an ESL context. Therefore, the specific objectives of this study are to explore English language 
teachers' belief of the different principles of CLT and the practice of CLT in the classroom.

\section{Conceptualising Teacher Belief}

The major shift in teaching has been a reconceptualization of it as a cognitive rather than behaviouristic phenomenon (Farrell \& Bennis, 2013). Conceptualising the belief of teachers is not easy because the definition of teachers' belief is wide ranging (Pajares, 1992). Based on the distinguishing factors, such as definition of beliefs, research methodology, and the relationship between beliefs and other factors, approaches to teacher belief conceptually can be theorised from three perspectives: nominative, metacognitive and contextual (Barcelos, 2003). The nominative approach considers teachers' belief to be an indicator of their teaching behaviour and describes and classifies the types of beliefs teachers have (Bernat \& Gvozdenko, 2005). Placed in the quantitative paradigm of research, studies of these kinds most often use the Likert-scale questionnaires to investigate belief e.g. Horwitz (1987). He initiated BALLI - Beliefs About Language Learning Inventory, which is a widely used model (see Mattheoudakis, 2007) to investigate teachers and learners' belief. Alternatively, the metacognitive approach defines belief as the collective knowledge that can be verbalised and gathered from the teachers' experiences that learners and teachers have about language learning and teaching (Barcelos, 2003). The advocated theory behind this approach is promoted by Wenden (2001). Amid the minimal number of studies that use this theory, the semi structured interview tends to be the tool used most often. The contextual approach, which is perhaps the widely used approach to explore the belief of the teachers' (Feryok, 2008; Mangubhai Marland \& Dashwood, 2004), views teacher's belief as embedded in contexts (Barcelos, 2003). Research studies within this approach are qualitative in nature and our based on and contribute toward an interpretive paradigm. The present study uses a socio-cultural theoretical framework to explore the formation of teachers' beliefs about teaching English using CLT and builds from the work conducted by Feryok (2008) and Mangubhai et al. (2004).

\section{Conceptualising Communicative Language Teaching}

CLT emerged as a reaction to the traditional Grammar Translation Method (GTM) and an interest in developing learners' communicative skills. CLT has been theorised by many experts, however, Richards and Rogers (2001) describe the most widely known CLT theory in use, which is as follows.

- Emphasis should be on the integration of linguistic form, meaning and function.

- Learners should be engaged in the pragmatic, authentic and functional use of language for meaningful purposes.

- Fluency and accuracy are complementary principles underlying communicative techniques.

- The principles of CLT also apply to reading and writing skills.

- Class teaching or learning should emphasise paired or group work.

- Errors are natural and should be tolerated.

- Evaluation should be carried out in terms of fluency and accuracy. 
According to Bachman and Palmer (1996), in order to promote communicative competence, the goal of CLT is to teach language by going beyond grammatical or language knowledge and to acknowledge the cultural and social context of the communication that is taking place. The key characteristic of CLT has always been emphasising meaning over accuracy of language. According to the philosophy of teaching and learning, it is contrary to the repetitive drilling of the Audio-Lingual Method (ALM) or the strict grammar rules of GTM. CLT focuses on the meaningful activities, both oral and written, to promote communicative competence in the learners (Larsen-Freeman and Anderson, 2011). CLT also advocates trial and error by the learners, which suggests teachers should tolerate the error in an effort to motivate students (Richards \& Rogers, 2001; Larsen-Freeman \& Anderson, 2011). The centre of power in a CLT classroom shifts from teachers to students by allowing them to interact and to provide ample opportunities to the students to be involved in pair or groups work. By doing so, teachers very naturally adopt the role of being a facilitator, rather than being the centre force of a language classroom.

\section{METHOD}

The present qualitative study was conducted to examine the relationship between teacher beliefs and observed classroom practices of the principles of CLT in an ESL context. Thus, the study aims to address the following research questions:

1. What is the English language teachers' belief regarding the principles of CLT in an ESL context?

2. How do English language teachers practice different principles of CLT in an ESL context?

The study is exploratory in nature, which is to satisfy a curiosity in some way, to explore or familiarise the researcher with the phenomenon that is under investigation and lead to a better understanding of it (Babbie, 2013, p.43). Considering the nature of the problem, the present study applied a case study method, which has received popularity among contemporary qualitative researchers (Creswell, 2013). Case study design was adopted for the study to facilitate in-depth understanding of what is to be studied and because case study research can accommodate the complexity of real-life events (Stake, 1995) through the social construction of the participants.

\section{Context}

The study was conducted during the month of January and February in two schools in Dhaka, Bangladesh. According to Kachru (1992), 'World Englishes' fall into three categories: Inner circle (who speak English as their native language); outer circle (their native language is not English, but use English as an additional institutionalised, official language); and expanding circles (very little institutional uses, and refers to English as a foreign language). Kachru (1992) favours keeping Bangladesh in the outer circle, where most of the South and South East Asian countries belong. CLT was introduced in Bangladesh in 1996 at the secondary level (Hamid, 2010). The CLT based curriculum is practiced in the schools to enhance the communicative skills in the learners, relying on 
the notion that commutative skills in English will open the avenue of building skilful workforce to contribute the country's economy (Hamid \& Honan, 2012).

The context of Dhaka is an urban setting; the schools are high performing ones with an overall passing rate of $97 \%$ and $93 \%$. However, the classrooms observed are not equipped with audio visual aids. The schools were chosen based on the availability of access. Four schools were approached in the same context and standard. Only the studied school was willing to participate. Every week has five working days in the school and English language classes are held in every day. Teaching materials, such as a textbook, whiteboard, marker pen, eraser etc. are provided by the school to the teachers.

\section{Participants}

The school has five teachers who teach English. Two teachers were needed for the study. The goal of case study is to get in-depth understanding regarding the subject being studied (Creswell \& Poth, 2017). The sample size was kept into two teachers in order to spend more time and to extract more information from the teachers regarding their belief of CLT. In a case study, even more than one case is enough to dilute the level of detail that could be provided (Wolcott, 2008). Therefore, the use of two teachers as case studies was sufficient

The first case, Rahim (Pseudonym), is a secondary school teacher in Dhaka, he is 26 years of age, has a Bachelor of Art in TESOL, is a non-native English language teacher, teaching English in the ESL context (Dhaka), and has experience of doing so for three years. He learned English in a Bengali medium school under the curriculum of CLT. After graduation, he joined the present school and attended further training under the National Curriculum and Textbook Board (NCTB).

The second case, Karim (Pseudonym), is also a secondary school teacher from the same city, he is 27 years old, he did a Bachelor in Applied Linguistics, he is a non-native English language teacher, and he has four years of experience in teaching within an ESL context. Karim learned English in a Bengali medium school under the same curriculum of CLT as Rahim. After graduation, he joined the present school and attended teacher training under the NCTB as well.

The sampling method, therefore, is a chosen purposeful sampling, which is very effective where the selected cases are involved in a program or even an activity (Stake, 1995). Both the teachers in the study are trained in TESOL, have knowledge about the modern philosophy of English teaching, and can explain their belief and demonstrate their practice. Homogeneousness (Miles \& Huberman, 1994) among the cases was maintained to comprise a collective case study about the belief of the ESL teacher as a subject of study (Van Hout \& Bingham, 2013). It helped to keep the study focused reduced and simplified (Miles \& Huberman, 1994).

\section{Data Collection}

Two instruments were used in data collection: the semi-structured interview and classroom observation. The paucity of existing studies is that they mostly used the questionnaire and interview data to obtain data (Farrell and Ives, 2014). However, very 
few studies have attempted classroom observation as the instrument to explore what teachers practice in their classrooms (Kuzborska, 2011). According to Nunan (1992) "there is no substitute for direct observation as a way of finding out about language in classrooms" (p.76). Therefore, the present study will bridge the gap in literature, but will also use several sources to collect additional data.

The data was collected during a two-week time. During that period, multiple sources of data were collected: one background interview about the participant, one semi structured interview of each participant, three non-participant observations of 30-minutes each, and follow-up post-lesson interviews for each teacher.

The semi-structured interview, according to McDonough and McDonough (1997) performs well as the principal research tool for gathering information about what respondents know and was used together the two teachers' beliefs about teaching English through CLT. Through the semi structured interview, both participants could express their belief regarding different aspects of CLT. The post observation was conducted to make sure teachers' act in the classroom, whether they faced any difficulty, if they could execute their stated belief in the classroom, and where they think their practice went different than their belief. The interviews were recorded, transcribed and cross checked by the participants, which helps to establish the internal validity of the study (Creswell \& Poth, 2017).

Observation, on the other hand, explored the practice of CLT in the classroom by systematically watching the two teachers teach. Four classroom observations, two for each teacher were held in two weeks. Data were collected by means of non-participant observation (McDonough and McDonough, 1997). During the classroom observations, being a non-participant observer, allow the researcher to sit back and record what transpired in the whole class without disrupting the natural environment of the classroom. A tape recorder was used to record the classes observed. Observation of the classes initiates the post observation interview and the basic discussion was the activities of the teacher in the classroom.

\section{Data Analysis}

Data analysis was ongoing and recursive (Lincoln \& Guba, 1985). The research questions guided the collection and analysis of data. When all of the observations and interviews were transcribed, they, along with the field notes, were coded and analysed. Findings from the different sources were validated through a triangulation process (Miles and Huberman, 1994). Transcripts were scanned repeatedly for recurring themes (Creswell \& Poth, 2017). Once this was concluded, they were compared with the other types of data (classroom observation notes and field notes) to discover similarities. Observations were checked against the transcripts before any conclusions were drawn. Before terminating data analysis, various member checks were performed whenever possible to elicit feedback from the teacher. Finally, beliefs and practices were summarised into charts; a comparison of the interview data and the observational data allowed for a comparison between beliefs and practices for each teacher. 


\section{FINDINGS}

Results of the study are summarised below. First, teachers' belief statements are reported, and then their classroom practices are explored.

\section{Teachers' Stated Beliefs}

Table 1 summarizes the belief statements of two teachers about language teaching in their particular classes. Findings are discussed based on the thematic categories listed in Table 1.

Table 1

Teachers' stated belief of CLT

\begin{tabular}{|c|c|c|c|}
\hline Theme & Belief & Rahim & Karim \\
\hline $\begin{array}{l}\text { Approach of } \\
\text { Language } \\
\text { teaching }\end{array}$ & $\begin{array}{l}\text { Language teaching approach should be: } \\
\text { - Integration of form and focus } \\
\text { - Grounded in a context or theme that the } \\
\text { students find interesting or relevant and } \\
\text { serves a function. }\end{array}$ & $*$ & $*$ \\
\hline $\begin{array}{l}\text { Oral and } \\
\text { Written } \\
\text { communicati } \\
\text { ve activities }\end{array}$ & $\begin{array}{l}\text { The ultimate goals of CLT activities are: } \\
\text { - To achieve oral communicative proficiency } \\
\text { - To achieve written communicative } \\
\text { proficiency }\end{array}$ & $*$ & $*$ \\
\hline $\begin{array}{l}\text { Classroom } \\
\text { Environment }\end{array}$ & $\begin{array}{l}\text { The classroom environment should patronise: } \\
\text { - Students are provided much of the time in } \\
\text { the classroom. } \\
\text { - Teachers should facilitate task in the } \\
\text { classroom. } \\
\text { - Learners should be involved in meaningful } \\
\text { collaborative work in the form of group } \\
\text { work and pair work. }\end{array}$ & $*$ & $*$ \\
\hline $\begin{array}{l}\text { Error } \\
\text { correction }\end{array}$ & $\begin{array}{l}\text { Statement regarding error correction: } \\
\text { - In written tasks, errors should be corrected } \\
\text { - In oral activities in the classroom } \\
\text { - Errors should be corrected to restrict } \\
\text { fossilization } \\
\text { - Students should not be interrupted for error } \\
\text { correction in the middle of a sentence }\end{array}$ & $*$ & $*$ \\
\hline $\begin{array}{l}\text { Use of } \\
\text { native } \\
\text { language }\end{array}$ & $\begin{array}{l}\text { Native Language should be used: } \\
\text { - In giving instruction in the classroom } \\
\text { - To explain something to the learners } \\
\text { - Translating the meaning }\end{array}$ & $\begin{array}{l}* \\
*\end{array}$ & $\begin{array}{l}* \\
*\end{array}$ \\
\hline
\end{tabular}

$(*)=$ Yes, $(-)=$ No.

The teachers are trained in contemporary TESOL approaches to teaching English. The summary of both the teachers' beliefs, therefore, seem to be consistent with the principles of CLT. Their stated belief is discussed further below. 
Karim and Rahim both expressed their approach to language teaching in the CLT classroom as being an integrated approach of form and function with an inductive approach to teaching grammar and vocabulary. For instance, Karim explained:

"CLT is an integrated approach to language learning, which incorporates all four skills of language learning as well as grammar and vocabulary in an inductive method through authentic or real-life materials (..) It allows learners to learn the function of the language"

All four skills of language should be the focus of successful CLT learners, and both Karim and Rahim seem to be in agreement. As Karim expressed: (the) learner should write and speak properly in order to communicate effectively. Therefore, they think all four skills should be incorporated in the lessons to teach effectively.

Both teachers believe that the CLT classroom should be learner-centred. They also believe that they are the one that should initiate tasks in the classroom and act as the facilitator of activities in the classroom. Learners should be involved in meaningful collaborative work through the means of group work and paired work. As Rahim mentioned: Class should prioritise students' centeredness. They should be involved in different tasks in group or in pairs.

Error correction is important to both Karim and Rahim in teaching English in an L2 classroom. They believe learners should be corrected by written and oral corrective feedback in writing and speaking. Thus, the error does not get fossilised in future use of the language. Karim expressed his belief: Error cannot be permitted, and I correct my students in communicative activities. Rahim believes: Error can be permanent if we do not correct them. However, to ensure fluency, I correct them after the speaking activity and in written work, it is always held after the class, in the means of homework. The way of which they correct the learners was found to be similar as well. They believe accuracy should be in the production, but not at the cost of accuracy.

According to what the teachers stated they believe, explaining meaning in the native language of learners has a crucial role in the instruction of L2. We use Bengali purposively for the benefit of students (Karim). As mentioned in the table below, they mostly used native language for three purposes, and it must be done due to the lack of vocabulary of learners. According to Rahim: They (students) want us to translate the meaning to Bengali. And they want us to explain the grammatical rules too, so that they can understand it further.

\section{Classroom Practices}

The practice of Rahim and Karim in their classroom is summarized below using a thematic manner and the information is described accordingly. 
Table 2

Teachers' practice of CLT in the classroom

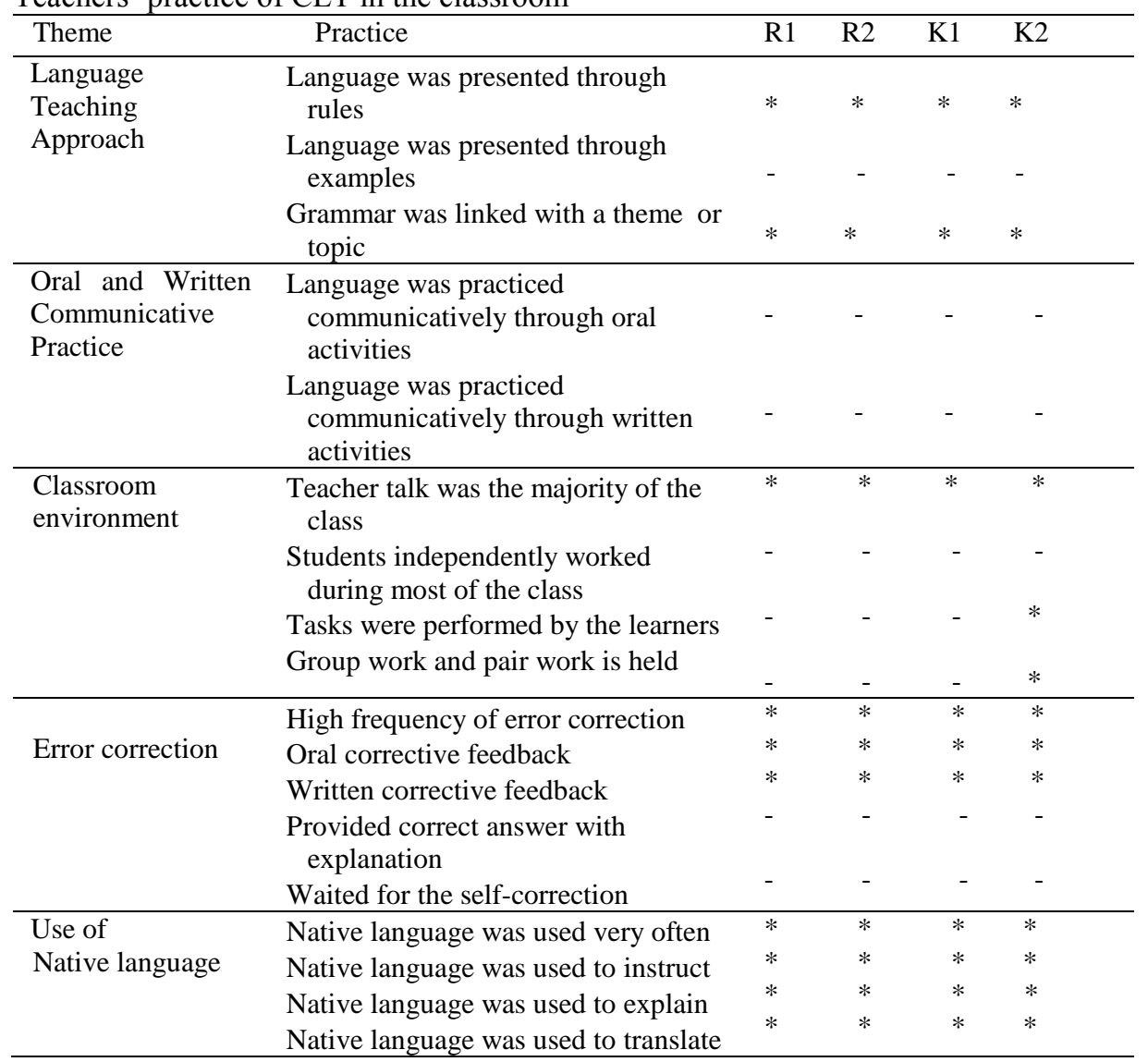

Both the observed classes of Karim were found to be similar in practice. The classes were 35 minutes in length. The lesson, however, was thematic and functional because the lesson was designed that way. The teaching approach observed contained the attributes of the deductive approach of teaching. Wherever students needed assistance to explain any rules or meaning of vocabulary, Karim relied on rules. The following incident exemplifies this:

ST: Teacher why "I go to school every day" and "My friend Mohammad goes school every day"

Karim: Because I is a first person. And Rifat is a third person.

Rahim, on the other hand, was found to practice the same approach and used the deductive approach to his classroom practice. His practice on the second lesson, however, was less deductive in nature, where he placed two examples before the 
students to understand. However, they explained the reason as being driven by a need of the learners. Rahim says:

You saw how students want explanations of everything since they are not proficient in English. And we have to narrate the explanation, otherwise in this big classroom and minimal amount of class time we would not able to finish the lesson.

The communicative classroom practices were also found to be rare in both Rahim's and Karim's observed classrooms. Classroom practices were mostly dominated by teacher talk and students were not communicating in English. They were not involved in any kind of oral communicative activities either. In two days of lessons, in the second lesson, one written communicative activity was held in Karim's classroom. They were asked about it after the class and explained it as the outcome of the exam-based education system where they have to rush to finish the lessons and do not allow students to frequently practice communicative activities. They also added the fact that listening and speaking are not assessed in the exam. This contributed to their reluctance to use oral communicative practices in the classroom. Therefore, memorisation still is found to be prevalent in their classrooms, especially due to the excessive pressure of exam marks and the guidance of schools' policy makers. Karim elaborated:

The only measuring factor here is the result in the exam. Communicative activity, therefore, becomes secondary. We have to answer everything to our senior teachers. And if students cannot do well in the exam, our evaluation will be bad. Even students and their parents are more concerned with the result, not the learning of language. Memorisation has an important role in this context.

The classroom of Karim was found to be teacher centred. In the first class, he organised group work for ten minutes and later could not complete the group work given the limitation of class time. The students were not involved in selecting the task either. Moreover, the learners were the passive entity in the whole lesson. The story of Rahim was not very different. The classroom was entirely lecture based, which made the students a passive audience who occasionally answered some closed-ended questions that warrant their presence in the classroom. In one occasion during the second lesson, Rahim grouped students for a task and it was pair work, and he could complete the task successfully. They were asked about their classroom environment, and they replied with same contextual obstacles that they explained earlier. Class size, class time, and exam oriented system.

Error correction was a feature of both the classrooms of Karim and Rahim. During the classes, Karim corrected a maximum amount of errors as described in the table. $\mathrm{He}$ explained it as following:

These are the errors I am correcting for years now for the students. I know they are not learned. If they do not learn it in my class, the error will persist further. I think, I do it for the learners and they improve by this. 
The mode of correction was both oral and written during one activity and in the written work. He did not even provide any examples when providing correction. Moreover, he seemed to be in a rush when providing the correction because he was not waiting for self-correction by the learners.

An improved atmosphere, however, was found in the class of Rahim, where error correction took place but in a more modified way. Although he provided correction, he made it inductive by providing examples and without providing direct examples. Besides this, he allowed some time for students to correct themselves. However, when students failed, he provided the correction.

The use of the native Bengali language was prevalent in the lessons in both the classrooms. Often, they used their native language in the instruction of L2 to serve four kinds of purposes that are presented in the table above. After the class Karim explained: You saw how students were demanding I explain the grammar rules and they need the meaning in the native language. Thus, we need to explain and translate. Similarly, Rahim says: Using Bengali (L1) is not our wish, it is the choice of students most of the time. They want to know new meaning and rules and they want to learn it in Bengali first. However, the teachers even used the native tongue to instruct. For instance, basic instruction like: Open the page number X (R1); or your homework will be for tomorrow $(\mathrm{K} 2)$, is given in the native language.

\section{DISCUSSION AND IMPLICATION}

The analysis presented in this study highlights the value of interpretive studies grounded in a descriptive understanding of what teachers do in the ESL classrooms by combining evidence of what the teachers believe regarding CLT and their practice with explanations in their own words.

The first research question examined teachers' belief of CLT. Overall, the common understanding of tasks we can extract from both the teachers is that it involved the integrated form and focus-oriented teaching, communicative work both written and spoken conducted in pairs or groups, student-centred classroom, which converge with the awareness of the different ways that CLT is defined in the literature them (Richards \& Rogers, 2001; Larsen-Freeman \& Anderson, 2011). This diverges with the belief with CLT regarding error correction and use of the native language. Considering the context of ESL, their beliefs were inclined to the use of native language to explain things better to the learners and giving corrective feedback to prohibit fossilization.

Teachers' belief in the ESL context highly depends on their learning as a learner and their teaching education. According to Richards and Lockhart (1994) 'teachers' beliefs about learning may be based on their training, their teaching experience, or may go back to their own experience as language learners' (p. 34). Bangladeshi ESL Teachers' in their learning history were the product of traditional Grammar Translational Method (GTM). Therefore, some of the features of GTM are still rooted in their belief like the use of native language and strict correction of students' errors. The phenomenon can be theorized by a contextual approach of teacher belief, which views teacher belief as embedded in the contexts (Barcelos, 2003). ESL teachers need to identify the mismatch 
between their existing belief and the philosophy of CLT by formatting their belief with new teaching techniques and strategy, instead of their longstanding experience of GTM.

The second research question was to identify the practice of Karim and Rahim in their classroom. The classroom practices of Karim and Rahim diverged from their stated belief and the theorized practice of CLT by Richards and Rogers (2001) and LarsenFreeman and Anderson (2011). The teaching of deductive practices and based on memorization of grammar rules and vocabulary; rare communicative activities; teachers' were the dominant force in the classroom, which are contradictory to their stated belief. However, their use of native language and error correction practice were found very much in line with their belief, though it diverged from the philosophy of CLT.

In their practice, what was found congruent is their view on error correction and use of native tongue. The error, according to them, should be corrected, as they stated it as their belief. Without correcting the error, the result can lead to fossilization. It was explained as the typical characteristics of ESL context. However, it was important to have a variety of techniques in error correction because all learners are not same and different students have different learning styles (Farrell and Bennis, 2013). Use of native language was found a frequent practice in the classroom by both the teachers. In the interview, they explained it as the learners' lack of proficiency of language. This is a critical finding for SLA research that how with the minimal of language skill in target language, the mother tongue can be avoided. However, these issues of belief and practice exclusively applies to the ESL context (Borg, 2003) and is what makes the teacher's belief and practice in the ESL context so critical than in its native counterpart.

Although, Karim and Rahim's belief regarding error correction and use of mother tongue is found in line in their practice, some other aspects of teaching practice are in opposition to their belief. Though the finding of the study cannot be generalised, the findings pose a real question towards the ESL pedagogy regarding error correction. How far these corrective feedbacks will help anyway to the achievement of L2 learners has been questioned by many researchers. It also important that giving feedback to young learners and adult learners may bring different results in the achievement of L2, considering the difference between the nature of L1 and L2 learners (Rahman, Pandian, Karim \& Shahed, 2017).

Furthermore, regarding the practice of grammar, Karim and Rahim frequently expressed that, as a teacher, they need to make choices about the time to devote to a single feature of grammar because the students' test encompasses them. Both Karim and Rahim explained in the post observation interview that the large number of students in the classroom forced the classes to be teacher-centred. Considering the fact that in a large classroom and the limited class time available where teachers need to complete the syllabus in a given time, teachers should take the lead and complete the syllabus within the given time. Farrell and Lim's (2005) study found similar constraints among teachers as well. The school context plays a vital role in ESL teachers' belief and practice (Oder $\&$ Eisenschmidt, 2016). It is an essential matter to consider that the users commonly belong to Asia and Africa, where the approach to teaching and learning is different than that is in West. And thus, the availability of school based professional development has 
become so important in shaping teachers' cognition effectively to bring any changes in their belief and practice in classroom (Karim, Mohamed \& Rahman, 2017).

This was the first time both teachers were asked about their beliefs and how they compared to their classroom practices. Indeed, prior to participation in this study, the two teachers were not consciously aware of their beliefs about teaching until they were asked directly about them during interviews. The point of reflecting on teacher belief and practice is not a matter of choosing the best belief or practice or method but exploring language teachers' beliefs and corresponding classroom practices that can help clarify how teachers can implement any changes to their approaches to teaching and learning over time. By doing this, teachers should recognise firstly, the mismatch between stated beliefs with CLT theories and, secondly, their stated belief and classroom practices is a natural phenomenon and may even be a process during professional development. Thus, it could be regarded as an opportunity rather than a fault or a shortcoming. The case study, therefore, will be used as the catalyst for ESL teachers to reflect upon their work, which as Richards and Lockhart suggest, posing questions about how and why things are the way they are, what value systems they represent, what alternatives might be available, and what the limitations are of doing things one way as opposed to another' (1994: 6).

\section{REFERENCES}

Andrews, S. (2003). 'Just like instant noodles': L2 teachers and their beliefs about grammar pedagogy. Teachers and Teaching, 9(4), 351-375.

Babbie, E. R. (2013). The basics of social research. Cengage Learning.

Bachman, L. F., \& Palmer, A. S. (1996). Language testing in practice: Designing and developing useful language tests (Vol. 1). Oxford University Press.

Barcelos, A. M. F. (2003). Teachers' and students' beliefs within a Deweyan framework: Conflict and influence. In Beliefs about SLA (pp. 171-199). Springer Netherlands.

Bernat, E., \& Gvozdenko, I. (2005). Beliefs about language learning: current knowledge, pedagogical implications, and new research directions. TESL-EJ, 9(1), n1.

Borg, S. (2003) Teacher cognition in language teaching: a review of research on what language teachers think, know, believe, and do. Language Teaching, 36(2), 81-109.

Chang, M., \& Goswami, J. S. (2011). Factors affecting the implementation of communicative language teaching in Taiwanese college English classes. English Language Teaching, 4(2), 3.

Creswell, J. W. (2013). Research design: Qualitative, quantitative, and mixed methods approaches. Sage publications.

Creswell, J. W., \& Poth, C. N. (2017). Qualitative inquiry and research design: Choosing among five approaches. Sage publications. 
Ellis, E. M. (2004). The invisible multilingual teacher: The contribution of language background to Australian ESL teachers' professional knowledge and beliefs. International Journal of Multilingualism, 1(2), 90-108.

Farrell, T. S., \& Ives, J. (2015). Exploring teacher beliefs and classroom practices through reflective practice: A case study. Language Teaching Research, 19(5), 594-610.

Farrell, T. S. C., \& Bennis, K. (2013). Reflecting on ESL teacher beliefs and classroom practices: A case study. RELC Journal, 44, 163-176.

Farrell, T. S. C., \& Lim, P. C. P. (2005). Conceptions of grammar teaching: A case study of teachers' beliefs and classroom practices. TESL-EJ, 9, 1-13.

Feryok, A. (2008). An Armenian English language teacher's practical theory of communicative language teaching. System, 36(2), 227-240.

Hamid, M. O. (2010). Globalisation, English for everyone and English teacher capacity: language policy discourse and realities in Bangladesh. Current Issues in Language Planning, 11(4), 289-310.

Hamid, M. O., \& Honan, E. (2012). Communicative English in the primary classroom: Implications for English-in-education policy and practice in Bangladesh. Language, Culture and Curriculum, 25(2), 139-156.

Horwitz, E. K. (1987). Surveying student beliefs about language learning. Learner strategies in language learning, 110129.

Humphries, S., \& Burns, A. (2015). 'In reality it's almost impossible': CLT-oriented curriculum change. Elt Journal, 69(3), 239-248.

Kachru, B. B. (Ed.). (1992). The other tongue: English across cultures. University of Illinois Press.

Karim, A., Mohamed, A. R., \& Rahman, M. M. (2017). EIA- A Teacher Education Project in Bangladesh: An Analysis from Diversified Perspectives. International Journal of Instruction, 10(4), 51-66. https://doi.org/10.12973/iji.2017.1044a

Kirkwood, A. (2013). English for communication in Bangladesh: Baseline research to establish the pre-existing environment for the 'English in Action'project. System, 41(3), 866-879.

Kuzborska, I. (2011). Links between teachers' beliefs and practices and research on reading. Reading in a foreign language, 23(1), 102-128.

Larsen-Freeman, D., \& Anderson, M. (2011). Techniques and Principles in Language Teaching 3rd edition. Oxford university press.

Lincoln Y. S., \& Guba E. G. (1985). Naturalistic Inquiry. Beverly Hills, CA: SAGE Publications. 
Mangubhai, F., Marland, P., Dashwood, A., \& Son, J. B. (2004). Teaching a foreign language: One teacher's practical theory. Teaching and Teacher Education, 20(3), 291311.

Mattheoudakis, M. (2007). Tracking changes in pre-service EFL teacher beliefs in Greece: A longitudinal study. Teaching and teacher education, 23(8), 1272-1288.

McDonough J,, \& McDonough S (1997) Research Methods for English Language Teachers. London: Arnold.

Miles, M. B., \& Huberman, A. M. (1994). Qualitative data analysis. London: Sage Publications.

Nunan, D. (1992). Research Methods in Language Learning. Cambridge: Cambridge University Press.

Nunan, D. (2003). The impact of English as a global language on educational policies and practices in the Asia-Pacific region. TESOL Quarterly, 37(4), 589-613.

Oder, T., \& Eisenschmidt, E. (2016). Teachers' perceptions of school climate as an indicator of their beliefs of effective teaching. Cambridge Journal of Education, 1-18.

Orafi, S. M. S., \& Borg, S. (2009). Intentions and realities in implementing communicative curriculum reform. System, 37, 243-253.

Pajares, M. F. (1992). Teachers' beliefs and educational research: Cleaning up a messy construct. Review of educational research, 62(3), 307-332.

Pandian, A. (2002). English language teaching in Malaysia today. Asia Pacific Journal of Education, 22(2), 35-52.

Phipps, S., \& Borg, S. (2009). Exploring tensions between teachers' grammar teaching beliefs and practices. System, 37(3), 380-390.

Rahman, M. M., Pandian, A., Karim, A., \& Shahed, F. H. (2017). Effect of age in second language acquisition: A critical review from the perspective of critical period hypothesis and ultimate attainment. International Journal of English Linguistics 7(5), 17.

Richards J. C. \& Lockhart C. (1994). Reflective teaching in second language classrooms. New York: Cambridge University Press.

Richards J. C. (1996). Teachers' maxims in language teaching. TESOL Quarterly 30(2), 281-96.

Richards, J. C. (2006). Communicative language teaching today. New York: Cambridge University Press.

Richards, J. C., \& Rodgers, T. S. (2001), Approaches and methods in language teaching: A description and analysis. Cambridge University Press, Cambridge.

Stake, R. E. (1995). The art of case study research. Sage. 
Van Hout, M. C., \& Bingham, T. (2013). 'Surfing the silk road': A study of users' experiences. International Journal of Drug Policy, 24(6), 524-529.

Wenden, A. L. (2001). Metacognitive knowledge in SLA: The neglected variable. Learner contributions to language learning: New directions in research, 4464.

Wolcott, H. F. (2008). Writing up qualitative research. Thoushand Oaks, CA: Sage. 